\title{
ARTIFICIAL RECHARGE OF GROUNDWATER
}

\author{
Herman Bouwer
}

\section{ABSTRACT}

Since planning for droughts must be done in wet cycles, storing surplus surface water behind dams or in aquifers is essential. Underground storage is enhanced by increasing the infiltration of water into the soil, using in-channel and off-channel spreading systems and basins. In-channel spreading is achieved with low dams or weirs that increase the width and depth of streams, or by constructing T- or L-dikes in the streambed to spread the water over the entire width of the bed. Off-channel systems are mostly specially constructed infiltration basins or old gravel pits. Contrary to what may intuitively be expected, shallow basins tend to give higher infiltration rates than deep basins because there is less compaction of clogging layers that accumulate on the bottom due to suspended solids and biological activity. This is demonstrated with a soils engineering analysis and with field data. Artificial recharge can also be important in temporary storage of water, for example, in connection with seasonal changes in the use of sewage effluent for irrigation or in the demand for drinking water. For the latter, such aquifer storage and recovery generally is much less expensive than building water treatment plants with enough peaking capacity or surface storage. Artificial recharge also can play a role in the reuse of wastewater because it provides treatment benefits, gives seasonal storage, and improves the aesthetics of water reuse by breaking up the pipe-to-pipe connection of direct reuse.

'Chief Engineer, U.S. Water Conservation Lab, ARS-USDA 4331 E. Broadway, Phoenix AZ 85040 


\section{$\underline{\text { Introduction }}$}

Storage of water in times of water surplus is becoming increasingly important to meet water demands in times of water shortage. Water shortages occur where demands exceed supplies, where over-pumping of groundwater diminishes groundwater resources, and where there are extended dry periods. The possibility of reduced rainfall due to global climatic changes and greenhouse effects is prompting water agencies to look at different scenarios so that they will be prepared for the future. Natural recharge of groundwater is particularly vulnerable to changes in rainfall, especially in zones with low rainfall where a small reduction in precipitation can cause a large reduction in groundwater recharge.

All these factors focus attention on increased storage, surface as well as underground storage. The latter is achieved through enhanced recharge of groundwater (for example, by vegetation management to reduce evapotranspiration) and by artificial recharge with surface infiltration systems or through injection wells. Sources of water for artificial recharge include any surplus surface water and water of impaired quality such as sewage effluent, storm runoff, or irrigation return flow.

\section{Infiltration Systems}

Infiltration systems require permeable soils, vadose zones without severely restricting layers that could cause excessive perched mounding, and unconfined aquifers with sufficient transmissivity for lateral flow through the aquifer without excessive mounding (Figure 1). Also, soils, vadose zones, and aquifers should not be contaminated with undesirable chemicals, and there should be no other water quality problems. Conventional infiltration systems can be grouped into in-channel and off-channel systems (Figure 2).

In-channel systems are weirs, dams or levees that spread the water over a streambed or flood plain, usually designed to be replaced or repaired after spring runoff or other flooding. Dams may be built with washout sections, while the smaller weirs and levees are considered expendable and easy to reconstruct completely. Off-channel systems may consist of old gravel pits or of specially built basins. These are most common in California, where there are hundreds of successful projects. Infiltration rates during inundation often range from 1 to $10 \mathrm{ft} /$ day. Year-round recharge systems with periodic drying and cleaning of the basins are typically rated at 100-1,000 ft/year. Periodic drying and cleaning are vital because soil clogging lowers infiltration rates. Silt, clay and other fines can accumulate to form clogging layers from less than 0.1 in. to more than $2 \mathrm{ft}$ thick. Even with clear water, biofilms can develop on the wetted perimeter, and algae can clog the bottom soil. 
logging tends to be more severe when the water is stagnant as in basins than hen it is moving as in recharge channels or T-levee systems. When filtration rates drop too low, drying the system shrinks and partially zcomposes algae, biofilms and other organic deposits. This may be sufficient - restore infiltration rates. Clogging material such as silt or clay deposits ust be physically removed from the bottom by "shaving" with a front-end ader, scraping or other means. Plowing or disking the clogging layers into e soil will improve the bottom temporarily, but the fines will then ;cumulate deeper in the soil so that eventually the entire top layer must be moved. Optimum lengths of flooding and drying periods depend on the soil, e suspended-solids content and nutrient levels of the water, and the climate. sme recharge systems in arid regions operate only during rain or flooding. ther cycles are controlled by environmental factors (insect breeding, odors, 1sightly floating algae) or recreational demands. Thus, cycles may vary from ur days flooding and 10 days drying to 11 months flooding and one month ying.

he water depth in infiltration basins should be carefully selected. The ydraulic heads of large water depths produce high infiltration rates, but they so tend to compress clogging layers, raising the hydraulic resistance of the Ittom. Thus, contrary to intuitive expectations, deep basins can produce iwer infiltration rates than shallow basins (Bouwer and Rice, 1989). Also, ie rate of turnover of the water in a deep basin may be less than in a shallow ssin, allowing more suspended algae to grow in longer exposure to sunlight. his aggravates the clogging by formation of an algal filter cake on the sttom, and by precipitation of calcium carbonate due to increases in the $\mathrm{pH}$ f the water resulting from uptake of dissolved carbon dioxide by hotosynthesizing algae.

he second design criterion is that the ground-water table must be deep rough below the infiltration system so that it does not interfere with the ifiltration process. This applies to the permanent water table and the lounding caused by recharging, as well as to perched ground-water mounds lat may form on restricting layers in the vadose zone. Where infiltration ttes are controlled by the clogging layer (which is the rule rather than the xception for basins and ponds), the water table must be $3 \mathrm{ft}$ or more below le bottom of the basin. Where there is no clogging layer, the vertical istance of the groundwater table below the water surface of the infiltration /stem at some distance from the ponds should be at least twice the width of te infiltration system if infiltration rates are not to be encumbered by roundwater levels. Thus where groundwater levels are high, maximum 
infiltration rates can then only be obtained with long narrow streams or basins spaced well apart. Equations have been developed to calculate the rise of groundwater mounds below infiltration systems (Bouwer, 1978, and references therein).

Infiltration systems must be tailored to local geohydrology, water quality and climate. In general, basins should be less than $2 \mathrm{ft}$ deep and hydraulically independent so that each can be flooded, dried and cleaned according to its best schedule. Inlet structures must not cause soil erosion that could clog basin bottoms. Drying periods should be started before infiltration rates have reached low values. Drying is then accomplished by infiltration, and pumping or draining the basins is not necessary. Finally, there should be a number of basins for flexible operation, with some in reserve to handle maximum water flows.

\section{Water Quality}

For relative pure water, the most important quality parameters for groundwater recharge are suspended solids (SS), total dissolved solids (TDS) and major cations such as calcium, magnesium and sodium. Periodic cleaning is necessary when SS causes clogging of the wetted perimeter of infiltration systems. Where the SS content is too high, the water is first passed through desilting or presedimentation basins to reduce cleaning costs. Coagulants may be added for this process, and on-site experiments will determine the best combination of pretreatment and cleaning schedules for hydraulic capacity and economy of operation. TDS and concentrations of calcium, magnesium and sodium determine whether a clay is dispersed or flocculated and therefore whether it has a relatively low or high hydraulic conductivity. This affects clay in the clogging layer and further down. Thus, TDS, calcium and magnesium should be high enough and sodium low enough to keep clay in the clogging layer and below in a flocculated, relatively permeable state.

In infiltration systems, recharging sewage effluent, storm runoff or other polluted water can improve its quality. Suspended solids are removed, biodegradable organic matter is decomposed, microorganisms are taken out, concentrations of nitrate and synthetic organic compounds are reduced, and phosphate and heavy metals are immobilized. Because of this, groundwater recharge can be used as a step in the treatment train for reuse of wastewater. It is then called soil-aquifer treatment (SAT) or geopurification (Bouwer, 1991).

To protect high-quality native groundwater and nearby drinking water wells, SAT systems are designed as recharge-recovery systems where recharge water is pumped out of the aquifer again with strategically located interceptors. The 
rater typically can be used as such for irrigation and recreation and, with Irther treatment, for drinking. SAT systems are inexpensive and simple to perate, and enhance the aesthetics of using recycled sewage for public water upplies by breaking the toilet-to-kitchen faucet connection. Special zgulations are being developed in California for blending of recharge water ith native groundwater to allow potable use of the water after SAT without ırther treatment (Hultquist et al., 1991).

\section{Vell Injection Systems}

iroundwater recharge with infiltration systems is not feasible where permeable urface soils are not available, vadose zones have restricting layers or are therwise unsuitable, or aquifers have poor quality water at the top or are onfined. For those conditions, groundwater recharge can be achieved with ijection wells. To prevent clogging of the aquifer interface around the xcharge well, the water should first be treated to remove all suspended solids. o minimize growths of biofilms, BOD, nutrients, and microorganisms should Iso be removed. Even then, a residual chlorine content still is necessary to ontrol bio-clogging of the well and aquifer. Thus, water for well injection hould be treated to essentially drinking water standards before it goes into the rell. In addition, the wells should be frequently pumped (about 10 minutes er day, for example) and periodically redeveloped, depending on decreases in pecific capacity for recharge. This makes groundwater recharge through rells much more expensive than recharge with infiltration basins. Where sclaimed sewage effluent is used for well injection, treatment benefits in the quifer tend to be relatively small because aquifers usually are coarse textured. lowever, SAT systems with well injection still offer the benefits of aesthetics nd improved public acceptance of water reuse (no pipe-to-pipe connection), nd some quality improvement ("aging" and "polishing" effects).

\section{يquifer Storage and Recovery (ASR) Wells}

เ new and rapidly spreading practice in artificial recharge is the ASR well. hese wells are combination recharge and pumping wells. They are used for xcharge when surplus water is available, and pumped when the water is eeded. ARS wells typically are used for seasonal storage of drinking water in reas where water demands are much greater in summer than in winter. rinking water treatment plants then are designed for mean annual capacity. he winter surplus is stored underground with ASR wells, which are pumped 1 the summer to augment the production from the water treatment plant. The nly treatment for the water from the wells then is chlorination. The ombination of mean flow capacity treatment plants and ASR wells is cheaper lan peak flow capacity treatment plants and no wells. 


\section{Artificial Recharge Issues}

Currently, there are three main issues in artificial recharge of groundwater: health effects, system sustainability, and artificial recharge under difficult soil and hydrogeological conditions. Concern about health effects occurs primarily in recharge systems where the source water is of low quality; i.e., sewage effluent, storm runoff, or agricultural runoff or return flow. The main concerns are about toxic organic compounds ("bad TOC!") that have survived the SAT process, and about disinfection byproducts (DBPs) if the water after SAT is chlorinated (other disinfection processes may also produce DBPs). DBPs can also be present in the water before SAT, if sewage effluent is chlorinated before discharge and the DBPs are not removed by SAT. For these reasons, it may be best to only mildly chlorinate or otherwise disinfect the effluent prior to infiltration, and then use UV after SAT when the turbidity of the water is very low for final disinfection. Humic and fulvic acids may be formed in the soil during SAT. These compounds are known THMprecursors. Thus, the water after SAT preferably should not be chlorinated but disinfected with other techniques such as UV.

In general, adverse health affects from drinking water after SAT or low quality input water can best be minimized by designing SAT systems with complete, systematic recovery of the recharge water from the aquifer. This then allows post-treatment of water after SAT with the appropriate technology (activated carbon filtration, reverse osmosis, UV irradiation) to minimize bad TOC and DBPs in the water. Where the recovery of water after SAT is with randomly distributed wells in the aquifer system, post treatment is difficult and dilution with unpolluted native groundwater is relied upon to get bad TOC and other toxic materials to low concentrations. For example, new California regulations would allow only 20 to $50 \%$ sewage derived water in the well water, depending on the treatment of the sewage prior to infiltration (Hultquist et a1., 1991).

Health effects are extremely difficult to assess. Epidemiological studies of the population drinking the water are extremely expensive and often inconclusive. Toxicological studies, including rodent bioassays on concentrates of the water after SAT, also may not be meaningful. Other health concerns are primarily microbiological and have to do with pathogens that may be ingested by eating raw vegetables irrigated with sewage water after SAT, inhaling aerosols, and accidental ingestion where water after SAT is used for swimming. There is also concern about contact with the water as with parks and playgrounds irrigated with the water, or farmers using the water for irrigation.

Sustainability of SAT systems has to do with the possible accumulation of certain minerals and organic compounds in the soil and aquifer and how this 
fects the underground environment. Most SAT processes are renewable and stainable (removal of $\mathrm{BOD}, \mathrm{NO}_{3}$, turbidity, and microorganisms). swever, some chemicals may go through SAT (refractory organics), and me may accumulate in the soil and aquifer (adsorbed organics, metals, 1osphate). Little is known about accumulating effects, although SAT systems nerally are considered as having very long useful lives (decades, centuries). ore knowledge on the sustainability of SAT and the proper closing and commissioning of SAT projects is needed.

:cause artificial recharge and SAT offer distinct advantages over other itions (surface storage, in-plant treatment), interest is growing in doing tificial recharge and SAT under unfavorable conditions, such as less rmeable soils, shallow bedrock, or restricting layers in the vadose zone. Ir such conditions, protocols for step-by-step site investigation procedures ust be set up to evaluate the conditions and to make sure that there are no atal flaws" that make recharge and SAT essentially impossible. The costs of ese investigations may be high, but the costs of an undetected fatal flaw may : much higher. SAT will be more expensive per acre foot of water for less vorable than for favorable conditions, but it may still be cheaper and more vantageous than other options.

onclusions

Itificial recharge with infiltration systems is an effective way for storing ter underground and for improving the quality of the water, especially if it sewage effluent or other water of low quality. Where surface infiltration is it feasible or possible, aquifers can be recharged through injection wells. lis process, however, requires pretreatment of the water to essentially inking water standards, and is much more expensive (often an order of agnitude more) than recharge with surface infiltration systems. Artificial charge is an important tool in water resources management, storing surplus ater during times of adequate supplies for use in times of water scarcity. rtificial recharge with full recovery of the water from the aquifer also will be 1 important tool for water reuse because it provides low cost treatment and srage of the water, and it enhances the aesthetics and public acceptance of ater reuse by breaking up the pipe-to-pipe connection of direct reuse of astewater. 


\section{REFERENCES}

1. Bouwer, Herman, 1978. Groundwater hydrology, McGraw-Hill, New York NY, $480 \mathrm{pp}$.

2. Bouwer, Herman, 1991. Groundwater recharge with sewage effluent. Water Sci. and Techn. 23:2099-2108.

3. Bouwer, Herman and R. C. Rice, 1989. Effect of water depth in groundwater recharge basins on infiltration. J. Irrig. and Drain. Eng. 115:556-567.

4. Hultquist, R.H., R. H. Sakaji, and T. Asano, 1991. Proposed California regulations for groundwater recharge with reclaimed municipal wastewater. Proc. 1991 Specialty Conference on Environmental Engineering, Am. Soc. Civ. Engrs, Reno, Nevada, 759-764. 